\title{
Reducing Labor Intensity when Computing Optimal Technical Characteristics of Aerial Ropeways
}

Alexander V. Lagerev
Vice Director
Academician I.G. Petrovskii Bryansk State
University
Institute of Fundamental and Applied
Researsh
Russia
Igor A. Lagerev
Professor
Academician I.G. Petrovskii Bryansk State
University
Russia

Alexander V. Lagerev

(nice Director d Applied

Russia

The article develops a procedure for optimizing the technical characteristics of ropeways - the step and the height of intermediate towers, and carrying ropes tension force. The optimization problem was based on the minimization of the tower structures cost. The reduction of computing labor intensity is based on the fact that the position of the minimum point of the objective function will be tied to one of the optimization restrictions. This allowed us to propose two ways to reduce the labor intensity of computing: a) reduction in the dimension of the optimization problem; b) replacement of the search for the minimum of the objective function with the solution of the nonlinear algebraic equation. The article shows that the proposed algorithm has increased computational efficiency. The algorithm allows us to obtain the same optimal values of technical characteristics of ropeways as in the solution of the previously developed optimization task but using simpler mathematical methods.

Keywords: aerial ropeway, intermediate tower, optimization, cost, step of towers, height of tower.

\section{INTRODUCTION}

Ropeways as overland transport systems have been widely used in many countries of the world as a continuous mode of transportation for freight and passenger travel [1-3]. Freight ropeways are used in many sectors of economy (mining, coal mining, chemicals production, metallurgy, energy, forestry, and agriculture) with the purpose of conveying process equipment within individual enterprises or providing logistic links to other enterprises, transport and storage terminals or construction sites $[4,5]$.

Passenger ropeways were originally used to improve the comfort of travel for people within sports or recreational facilities [2, 6]. However, since the 1990s, passenger ropeways have become quite actively used as extra-street mode of public transportation in large metropolitan cities [7, 8], and also as passengers traveling facility within tourist, recreational and natural territories $[9,10]$. Currently, passenger ropeways are being operated in every continent, but most of them are located in Europe (Germany, Austria, France, Italy, Switzerland, Russia), America (Bolivia, Colombia, Venezuela) and Asia (China, India, Vietnam). A detailed overview of ropeways use in different countries can be found in [2, $11,12]$

The use of passenger aerial ropeways as urban transport can solve transport problems which are impossible to be fixed by traditional land transport (wheeled, rail or conveyor ones) $[13,14]$. The advantages of ropeway transport are particularly evident when such factors as terrain, high density of residential or industrial

Received: February 2020, Accepted: September 2020

Correspondence to: Prof. Dr Alexander V. Lagerev

Academician I.G. Petrovskii Bryansk State University,

Bezhitskaya ulitsa 14, 241036 Bryansk 36, Russia

E-mail: avl-bstu@yandex.ru

doi: 10.5937/fme2101072L

(C) Faculty of Mechanical Engineering, Belgrade. All rights reserved buildings and various urban planning restrictions hinder the development of land transportation [2, 15]. Also, according to existing feasibility studies $[7,13,16]$ ropeway transport is more economically and environmentally friendly than land transport. Therefore, it can be said that passenger aerial ropeways in an urban environment are a socially attractive and economically efficient type of transport. As shown in $[3,11,17]$, passenger ropeways are now increasingly being regarded as an efficient alternative to traditional land public transport modes in large cities.

\section{ANALYSIS OF THE RESEARCH PROBLEM}

The problem of the study of passenger aerial ropeways is complex, as it has several scientific aspects - technical, economic, social, and legal ones. Most of the existing studies are devoted to engineering problems of design and calculation of basic structural elements of ropeways, for example, analysis of dynamics and strength of carrying ropes [18, 19] or risk analysis of ropeways operation [20]. Also, for example, [15] considered the issues of social and economic impact of ropeways construction on the development of adjacent territories, [21] - issues of legal registration of the ownership for air space and land for ropeways.

Economic challenges of ropeways construction have not yet been widely considered, although they determine the prospects of urban transport infrastructure modernization based on ropeways. Economic studies tend to assess the economic impact of replacing the existing land transport system with an alternative ropeway. The issues of identifying most appropriate technical characteristics of ropeways based on the need to minimize construction costs, have not yet been studied. Such topics are discussed, for example, in [22-24].

Construction of passenger ropeways in a highly urbanized environment of a large city or metropolis is a 
very expensive technical and economic task $[2,25]$. The cost of construction includes the cost of survey, construction, installation and design works, purchase of mechanical equipment, development of an automated system of traffic control, etc. A significant component in the total cost of ropeways is the cost of manufacturing and installation of intermediate towers along the ropeway line, purchase of traction and carrying steel ropes and of technological equipment.

As shown in $[2,23]$, the task of ropeways intermediate towers construction is a complex task of technical and economic optimization. The purpose of the optimization is to ensure the minimum cost of intermediate towers construction, purchase traction and carrying ropes, as well as a set of technological equipment to be installed on the towers. The setting and solution of this optimization problem allow for a significant reduction of passenger aerial ropeways costs in an urbanized environment $[22,23]$.

One approach to the analysis of the economic component of the problem of urban public transport system modernization based on passenger aerial mechatronic ropeways and to the development of corresponding optimization mathematical models was proposed in [2, 25]. Figure 1 shows a design of an aerial ropeways section between two adjacent intermediate towers.

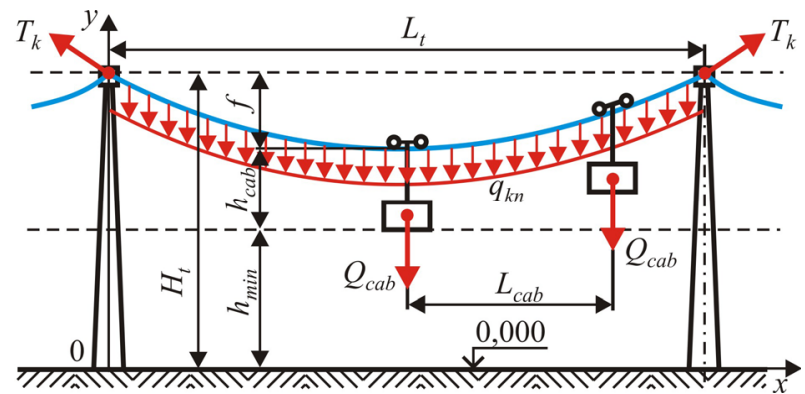

Figure 1. Calculation scheme of aerial ropeways section between adjacent intermediate towers

Two independent values were proposed to be used as variable optimization parameters of ropeways intermediate towers installation step: towers step $L_{t}$ and carrying ropes tension force $T_{k}$. Based on them, a vector of controlled parameters [2] was developed:

$$
\{x\}^{T}=\left\{x_{1} x_{2}\right\}=\left\{L_{t} T_{k}\right\} .
$$

Other technical and economic characteristics of ropeways are proposed to be regarded as fixed: they are either specified as input data or calculated depending on the specified managed parameters. The first group includes $[2,25]$ : ropeway total length $L_{t r}$, passenger cabins distance $L_{c a b}$, passenger cabin weight $Q_{c a b}$, permissible height approximation of the passenger cabins to buildings and structures $h_{\min }$, cabin height $h_{c a b}$, dynamic factor $\psi_{d}$, minimum rope safety factor $[n]_{k}$, number of carrying ropes $n_{k n}$, empirical coefficients for calculating the cost of the intermediate tower foundation $C_{f 0}$ and $a_{f}$, empirical coefficients for calculating the cost of the intermediate tower $C_{t 0}$ and $a_{t}$, empirical coefficient for calculating the own weight of 1 linear meter of rope length $q_{k 0}$, empirical coefficients for calculating the breaking force of the rope $r_{k 0}, r_{k 1}$ and $r_{k 2}$, empirical coefficients for calculating the cost of 1 linear meter of rope length $c_{k 0}, c_{k 1}$ and $c_{k 2}$. The second group includes [2, 26]: intensity of distributed load from rope own weight $q_{k n}$, intensity of distributed load from passenger cabin weight $q_{c a b}$, carrying ropes sagging deflection in the span between adjacent intermediate towers $f$, diameters of traction $d_{k t}$ and carrying $d_{k n}$ ropes, geometric height of intermediate tower $H_{t}$, rope length in the span between adjacent intermediate towers $l_{k}$, number of intermediate towers $n_{t}$. It was proposed to form a vector of uncontrollable parameters based on the values in the second group. These parameters are not subject to variation in the process of the optimization problem solving:

$$
\begin{aligned}
& \{z\}^{T}=\left\{\begin{array}{llllllll}
z_{1} & z_{2} & z_{3} & z_{4} & z_{5} & z_{6} & z_{7} & z_{8}
\end{array}\right\}= \\
& =\left\{q_{k n} q_{c a b} f d_{k t} d_{k n} H_{t} l_{k} n_{t}\right\} .
\end{aligned}
$$

As a result, the task of complex technical and economic optimization of aerial ropeways intermediate towers installation step is reduced to the minimization of the objective function - the total cost of manufacturing and installation of towers, purchase of traction and carrying ropes. According to $[2,26]$, the objective function is written as:

$$
\begin{aligned}
& O(\{x\},\{z\})=\frac{L_{t r}}{x_{1}}\left\langleC _ { f 0 } \left\{\left[h_{\min }+h_{c a b}+\frac{\psi_{d}\left(z_{1}+z_{2}\right) x_{1}^{2}}{8 x_{2}}\right] \times\right.\right. \\
& \left.\times\left(1+\frac{x_{2}[n]_{k}}{R_{k n}}\right)\right\}^{a_{f}}++C_{t 0}\left\{\left[h_{\min }+h_{c a b}+\frac{\psi_{d}\left(z_{1}+z_{2}\right) x_{1}^{2}}{8 x_{2}}\right] \times\right. \\
& \left.\left.\times\left(1+\frac{x_{2}[n]_{k}}{R_{k n}}\right)\right\}^{a_{t}}+C_{e}\right\rangle+ \\
& +\left(C_{k t}+n_{k n} C_{k n}\right) L_{t r}\left[1+\frac{\psi_{d}^{2}\left(z_{1}+z_{2}\right)^{2} x_{1}^{2}}{24 x_{2}^{2}}\right] \rightarrow \min
\end{aligned}
$$

And the following should be valid - the restrictions in the form of inequalities [2] which determine the requirements for:

- allowable range of change of step between adjacent towers

$$
x_{1} \geq 0 ; \quad L_{t \max }-x_{1} \geq 0 ; \quad L_{t r} / x_{1}-1 \geq 0 ;
$$

- allowable ranges of traction and carrying ropes diameters

$$
\begin{array}{ll}
d_{k t \text { max }}-d_{k t} \geq 0 ; & d_{k t}-d_{k t \text { min }} \geq 0 ; \\
d_{k n \text { max }}-d_{n t} \geq 0 ; & d_{k n}-d_{k n \text { min }} \geq 0 ;
\end{array}
$$

- maximum allowable carrying rope sagging between the towers

$$
\psi_{f} x_{1}-\frac{\psi_{d}\left(z_{1}+z_{2}\right) x_{1}^{2}}{8 x_{2}} \geq 0 ;
$$


- minimum rope tension force

$$
x_{2}-10 n_{c a b} \psi_{d} Q_{c a b} / n_{k n} \geq 0 ;
$$

- maximum rope tension force, based on its greatest possible aggregate strength

$$
R_{k n}\left(d_{k n \max }\right) /[n]_{k}-x_{2} \geq 0 ;
$$

- maximum intermediate tower height

$$
H_{t \text { max }}-h_{\text {min }}-h_{c a b}-\frac{\psi_{d}\left(z_{1}+z_{2}\right) x_{1}^{2}}{8 x_{2}} \geq 0,
$$

where $L_{t \max }$ - limit distance between intermediate towers; $d_{k t \text { max }}\left(d_{k t \text { min }}\right), d_{k n \text { max }}\left(d_{k n \text { min }}\right)$ - maximum (minimum) traction and carrying ropes diameter; $\psi_{f}$ - factor of allowable rope sagging between the towers; $n_{c a b}$ number of passenger cabins simultaneously within one span; $R_{k n}\left(d_{k n \text { max }}\right)$ - maximal diameter rope breaking force at the chosen structure; $H_{t \text { max }}$ - maximum permissible intermediate tower height.

\section{PROCEDURE FOR REDUCING OPTIMIZATION CALCULATION LABOR INTENSITY}

In $[2,26]$ the solution of the specified optimization problem (3) was performed taking into account the above constraints on variables - distance between intermediate towers $L_{t}$ and tension force of carrying ropes $T_{k}$. For this purpose, one of the direct methods of nonlinear conditional optimization of Hooke-Jeeves pattern moves [27] was used.

Calculations showed that within the limits of the initial parameters of the optimization problem $L_{t r}$, $L_{c a b}, Q_{c a b}, h_{\min }, h_{c a b}, \psi_{d},[n]_{k}, C_{f 0}, a_{f}, C_{t 0}, a_{t}$, $q_{k 0}, \quad r_{k 0}, \quad r_{k 1}, r_{k 2}, c_{k 0}, c_{k 1}, c_{k 2}$, the characteristics of modern passenger aerial ropeways cabins, the minimum point of the objective function (3) lies on the constraint (8). Thus, its position is determined by the carrying rope minimum tension force. The minimum point is located at a sufficient distance from the possible points of intersection of the constraint (8) with any other constraint of the optimization problem.

This fact leads to the conclusion that the position of the minimum point of the objective function (3) in the two-dimensional space $\{x\}^{T}=\left\{x_{1} x_{2}\right\}=\left\{L_{t} T_{k}\right\}$ can be searched not in the entire space, but only along the constraint line (8). Given that the constraint line minimum point location (8) is determined by

$$
x_{2}-10 n_{c a b} \psi_{d} Q_{c a b} / n_{k n}=0,
$$

we can immediately determine the optimal value of one of the variable parameters of the optimization problem:

$$
x_{2}^{o p t}=T_{k}^{o p t}=10 n_{c a b} \psi_{d} Q_{c a b} / n_{k n} .
$$

For calculation purposes, $x_{2}^{o p t}=T_{k}^{o p t}$ using (12) the number of passenger cabins shall be taken as $n_{c a b}=1$.
Therefore, when optimizing the objective function (3) it is necessary to determine the optimal value of only one variable parameter - Tintermediate towers step $x_{1}^{o p t}=L_{t}^{o p t}$. Thus, the initial problem of two-dimensional optimization is reduced to a mathematically simpler one-dimensional problem of nonlinear optimization.

The fact that the minimum point of the objective function (3) does not coincide with any points of intersection of the constraint (8) with other constraints further simplifies the procedure of solving the optimization problem. It turns into a problem of unconditional nonlinear optimization. Its solution is possible both via effective numerical methods and analytically. Naturally, the optimal intermediate towers step value $x_{1}^{\text {opt }}=$ $L_{t}^{\text {opt }}$ obtained as a result of the solution should be checked for its compliance with the other constraints of the optimization problem.

So the objective function (3) can be written as

$$
\begin{aligned}
& O\left(x_{1},\{z\}\right)=\frac{L_{t r}}{x_{1}}\left\langleC _ { f 0 } \left\{\left[h_{\min }+h_{c a b}+\frac{\psi_{d}\left(z_{1}+z_{2}\right) x_{1}^{2}}{8 T_{k}^{o p t}}\right] \times\right.\right. \\
& \left.\times\left(1+\frac{T_{k}^{o p t}[n]_{k}}{R_{k n}}\right)\right\}^{a_{f}}+C_{t 0}\left\{\left[h_{\min }+h_{c a b}+\frac{\psi_{d}\left(z_{1}+z_{2}\right) x_{1}^{2}}{8 T_{k}^{o p t}}\right] \times\right. \\
& \left.\left.\times\left(1+\frac{T_{k}^{o p t}[n]_{k}}{R_{k n}}\right)\right\}^{a_{t}}+C_{e}\right\rangle+ \\
& \left(C_{k t}+n_{k n} C_{k n}\right) L_{t r}\left[1+\frac{\psi_{d}^{2}\left(z_{1}+z_{2}\right)^{2} x_{1}^{2}}{24\left(T_{k}^{o p t}\right)^{2}}\right] \rightarrow \min
\end{aligned}
$$

or shorter

$$
\begin{aligned}
& O\left(x_{1},\{z\}\right)=\frac{1}{x_{1}}\left[A_{f}\left(H+B x_{1}^{2}\right)^{a_{f}}+A_{t}\left(H+B x_{1}^{2}\right)^{a_{t}}+C_{e}\right]+ \\
& +A_{k}\left(1+D x_{1}^{2}\right) \rightarrow \min ,
\end{aligned}
$$

where

$$
\begin{aligned}
& A_{f}=L_{t r} C_{f 0}\left(1+\frac{T_{k}^{o p t}[n]_{k}}{R_{k n}}\right)^{a_{f}} ; \\
& A_{t}=C_{t 0}\left(1+\frac{T_{k}^{o p t}[n]_{k}}{R_{k n}}\right)^{a_{t}} ; \\
& A_{k}=\left(C_{k t}+n_{k n} C_{k n}\right) L_{t r} ; \\
& B=\frac{\psi_{d}\left(z_{1}+z_{2}\right)}{8 T_{k}^{o p t}} ; \\
& D=\frac{\psi_{d}^{2}\left(z_{1}+z_{2}\right)^{2}}{24\left(T_{k}^{o p t}\right)^{2}} ; \\
& H=h_{\min }+h_{c a b} .
\end{aligned}
$$

Finding the minimum of the objective function (13) of one variable $x_{1}$ can be performed by one of numerical methods of unconditional optimization [27]. 
There can be a different approach to finding $x_{1}^{\text {opt }}=L_{t}^{\text {opt }}$. Given that at the minimum point of $x_{1}^{\text {opt }}=L_{t}^{\text {opt }}$ objective function (13), the following condition is valid

$$
\frac{d}{d x_{1}} O\left(x_{1},\{z\}\right)=0,
$$

$x_{1}^{\text {opt }}=L_{t}^{\text {opt }}$ we get a nonlinear algebraic equation written as follows to determine the desired value:

$$
\begin{aligned}
& 2 A_{k} D\left(x_{1}^{o p t}\right)^{3}+2\left\{A_{f} a_{f}\left[H+B\left(x_{1}^{o p t}\right)^{2}\right]^{a_{f}-1}+\right. \\
& \left.+A_{t} a_{t}\left[H+B\left(x_{1}^{\text {opt }}\right)^{2}\right]^{a_{t}-1}\right\}\left(x_{1}^{\text {opt }}\right)^{2}- \\
& -\left\{A_{f}\left[H+B\left(x_{1}^{\text {opt }}\right)^{2}\right]^{a_{f}}+A_{t}\left[H+B\left(x_{1}^{\text {opt }}\right)^{2}\right]^{a_{t}}+C_{e}\right\}=0
\end{aligned}
$$

Equation (17) can be solved using one of the numerical methods of solving algebraic equations [28].

If the determined value is

$$
x_{1}^{o p t}=L_{t}^{o p t} \in\left(L_{c a b} ; 2 L_{c a b}\right],
$$

there will be two passenger cabins between the adjacent intermediate towers within one span. Therefore, it is necessary to conduct a new iteration of determining the optimal step value $x_{1}^{\text {opt }}=L_{t}^{\text {opt }}$. To do this, we need to calculate new values $x_{2}^{o p t}=T_{k}^{o p t}$ using (12) and uncontrollable parameter $z_{2}$ using equation

$$
z_{2}=\frac{n_{c a b} Q_{c a b}}{n_{k n} L_{c a b}},
$$

using in the specified equations the value $n_{c a b}=2$.

Similarly, if the determined value is

$$
x_{1}^{o p t}=L_{t}^{o p t} \in\left(2 L_{c a b} ; 3 L_{c a b}\right],
$$

there will be three passenger cabins between the adjacent intermediate towers within one span. The new values $x_{1}^{o p t}=L_{t}^{o p t}$ and $z_{2}$ need to be calculated at $n_{c a b}=$ 3. And so on.

Based on the determined intermediate towers step optimal values $L_{t}^{\text {opt }}$ and carrying ropes tension force $T_{k}^{o p t}$ other basic technical characteristics of passenger aerial ropeways can be calculated according with the following dependencies:

- intermediate towers height

$$
H_{t g}=h_{\min }+h_{c a b}+\frac{\psi_{d}\left(z_{1}+z_{2}\right)\left(L_{t}^{o p t}\right)^{2}}{8 T_{k}^{o p t}} ;
$$

- carrying rope length within one span

$$
l_{k}=L_{t}^{o p t}\left[1+\frac{\psi_{d}^{2}\left(z_{1}+z_{2}\right)^{2}\left(L_{t}^{o p t}\right)^{2}}{24\left(T_{k}^{o p t}\right)^{2}}\right] ;
$$

- carrying rope diameter

$$
d_{k n}=\frac{\sqrt{r_{k 1}^{2}-4 r_{k 2}\left\{r_{k 0}-[n]_{k}\left(T_{k}^{o p t}\right)\right\}}-r_{k 1}}{2 r_{k 2}} .
$$

\section{ANALYSIS OF CALCULATION RESULTS}

To calculate the optimal value of carrying ropes tension force, (12) can be written as

$$
x_{2}^{o p t}=T_{k}^{o p t}=10 \psi_{d} L_{c a b} z_{2} .
$$

This expression shows that at the specified distance between passenger cabins $L_{c a b}$ the value $T_{k}^{o p t}$ is determined by the intensity of the distributed load on the carrying rope from the weight of the passenger cabin $z_{2}$. The ratio of the passenger cabin weight and the distance between the cabins at the same value $z_{2}$ for the two characteristic values of 20 and $40 \mathrm{~N} / \mathrm{m}$ is shown in Figure 2 .

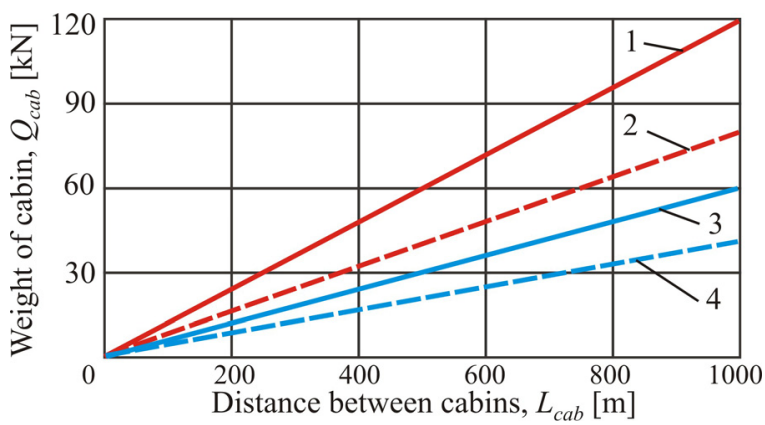

Figure 2. Ratio of the passenger cabin weight and the distance between the cabins at the same value $z_{2}: 1-, z_{2}=40$ $\mathrm{N} / \mathrm{m}, n_{k n}=2 ; 2-z_{2}=40 \mathrm{~N} / \mathrm{m}, n_{k n}=1 ; 3-z_{2}=20 \mathrm{~N} / \mathrm{m}, n_{k n}=2 ; 1$ $z_{2}=20 \mathrm{~N} / \mathrm{m}, n_{k n}=1$

To compare the results of calculations carried out by optimizing the objective function of two variables (3) proposed in [26] and the objective function of one variable (13) proposed in this research, these calculations were performed with the same initial data as in [26]. Two variants of the ropeways were considered based on the use of towers similar in cost to MPG500 and MU330 towers, with two carrying and one traction rope according to Russian standard GOST 3079-80 of marking group $G_{k}=2160 \mathrm{MPa}$.

Calculations following the proposed simplified algorithm, showed that the positions of the minimum points of objective functions (13) and (3) exactly coincided. This testifies to the adequacy of the proposed approach to the accelerated optimization assessment of aerial ropes key technical characteristics.

Figure 3 shows the diagrams of change of the value of objective functions (3) along the constraint (8) depending on intermediate towers step $L_{t}$. All diagrams (for all structural types of intermediate towers) have a qualitatively similar extreme shape. However, they depend quantitatively on the type of intermediate towers used. The extremum is more pronounced when the value of the intermediate towers optimal step $L_{t}^{\text {opt }}$ is less. This can be explained by the fact that the cost of intermediate towers is expressed by an exponential function of their height $H_{t}$, and the rate of growth of the tower cost with height increase, is different for towers of different design $[2,26]$. 


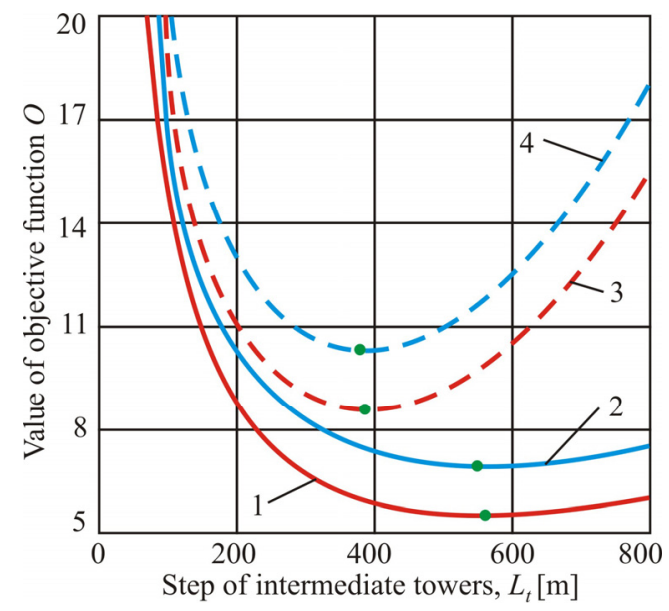

Figure 3. Change of objective function (13) value along the constraint (8) depending on the intermediate towers step: 1 - MPG500 towers, $z_{2}=20 \mathrm{~N} / \mathrm{m} ; 2-$ MPG500 towers, $z_{2}=40$ $\mathrm{N} / \mathrm{m} ; 3-$ MU330 towers, $z_{2}=20 \mathrm{~N} / \mathrm{m} ; 4-$ MU330 towers, $z_{2}=$ $40 \mathrm{~N} / \mathrm{m}$

Figure 4 provides a comparison of changes in the unit cost $C_{t}$ for MPG500 and MU330 intermediate towers depending on their installation step, as well as the diagram of tower height change. It can be seen that (MU330) towers characterized by a higher rate of growth of their cost with height increase, correspond to a more pronounced extreme form of dependence $O\left(L_{t}\right)$ and lower values of intermediate towers optimal step $L_{t}^{\text {opt }}$. The explanation for this is as follows: if such intermediate towers are used, it is economically advantageous to install lower towers, even though their spacing should be smaller and the total number within the ropeway should be bigger. In this case, the trend of increasing costs when using higher towers prevails over the other trend - the increasing cost of installing more towers. On the other hand, (MPG500) towers, characterized by a relatively low rate of growth of their cost with height increase, correspond to a less pronounced extreme form of dependence $O\left(L_{t}\right)$ and large values of intermediate towers optimal step $L_{t}^{\text {opt }}$. In this case, on the contrary, the trend of increasing cost of installing more towers prevails over the other trend - the increasing cost of using higher towers.

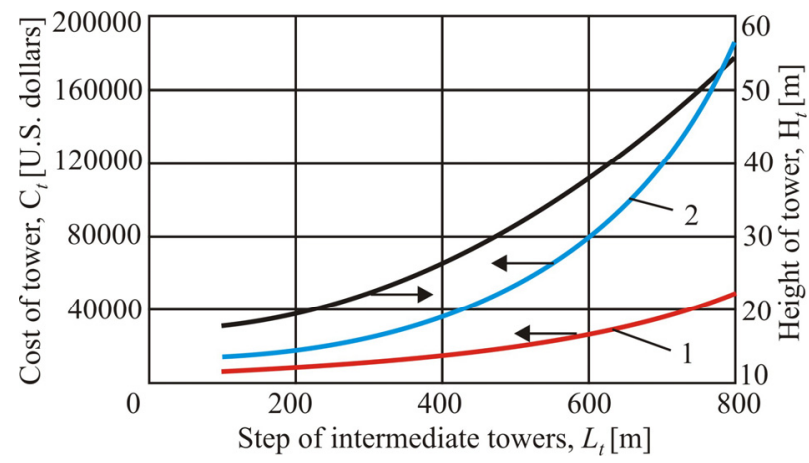

Figure 4. Dependence of height and unit costs of intermediate towers on the step of their installation: 1 - MPG500 towers; 2 - MU330 towers

\section{CONCLUSION}

The method of accelerated optimization estimation of key technical characteristics of aerial ropeways (installation step and intermediate tower height, carrying ropes tension forces) considered in the article allows to obtain exactly the same values as the result of solving the general problem of technical and economic optimization formulated in $[2,26]$. It has increased computational efficiency, as it is based on the use of simpler mathematical methods, requires less time and computational resources for carrying out optimization calculations.

The proposed method can be recommended for the initial stages of aerial ropeways project development. It allows to quickly determine the optimal values of key technical characteristics of the designed ropeways for a large number of possible combinations of intermediate towers designs, types and dimensions of carrying ropes, cost of technological equipment. Comparative analysis of the results of these calculations provides for the development of an optimally reasoned design solution.

\section{ACKNOWLEDGEMENT}

The study was supported by Presidential Grant for Governmental Support tof Young Russian Scientists No. MD-422.2020.8

\section{REFERENCES}

[1] Scheingert, Z.: Aerial Ropeways and Funicular Railways, Pergamon, London, 1966.

[2] Korotkiy, A. A., Lagerev, A. V., Meskhi, B. Ch., Lagerev, I. A., Panfilov, A. V.: The development of transport infrastructure of large cities and territories on the basis of technology of passenger ropeways, DGTU, Rostov-na-Donu, 2017. (in Russian)

[3] Hoffmann, K.: Recent Developments in CableDrawn Urban Transport Systems, FME Transactions, Vol. 34, No. 4, pp. 205-212, 2006.

[4] Pestal, E.: Seilbahnen und Seilkrane in Holz und Materialtransport, Fromme, Wien, 1961.

[5] Material Ropeway [site]: https://www.doppelmayr. com/products/material-ropeway/.

[6] Hoffmann, K. and Zrnić, N.: A Contribution on the History of Ropeways, in: Koetsier, T. and Ceccarelli, M. (Eds): Explorations in the History of Machines and Mechanisms. History of Mechanism and Machine Science, Springer, Dordrecht, Vol. 15, pp. 381-394, 2012.

[7] Neumann, E.: Cable Propelled People Movers in Urban Environments, Transportation Research Record: J. of the Transportation Research Board, No. 1349, pp.125-132, 1992.

[8] Alshalalfah, B., Shalaby, A. and Dale, S.: Experiences with Aerial Ropeway Transportation Systems in the Urban Environment, J. of Urban Planning and Development, Vol. 140, No. 1, 04013001, 2014.

[9] Sever, D.: Some new methods to ensure harmonisation of sustainable development of mountain resorts ropeway, Promet-Traffic \& Transportation, Vol. 14, No. 5, pp. 213-220, 2002.

[10] Tezak, S.: Modern Cableways - The Base of Mountain Sports Tourism, in: Kasimoglu, M. and 
Aydin, H. (Eds): Strategies for tourism industry, Intech Open, pp. 297-312, 2012.

[11] Vucnic, V. R.: Urban transit systems and technology, John Wiley and Sons, Hoboken, New Jersey, 2007.

[12] Alshalalfah, B., Shalaby, A., Dale, S. Othman, F.: Improvements and Innovations in Aerial Ropeway Transportation Technologies: Observations from Recent Implementations, J. of Transportation Engineering, Vol. 139, No. 8, pp. 814-821, 2013.

[13] Neumann, E. S., Bonasso, S. and Dede, A. D. I.: Modern Material Ropeway Capabilities and Characteristics, J. of Transportation Engineering, Vol. 111, No. 6, 1985.

[14] Beňo, P., Krilek, J., Kováč, J., Kozak, D. and Fragassa, C.: The Analysis of the New Conception Transportation Cableway System Based on the Tractor Equipment, FME Transactions, Vol. 46, No. 1, pp. 17-22, 2018.

[15] Nikšić, M., Gašparović, S.: Geographic and Traffic Aspects of Possibilities for Implementing Ropeway Systems in Passenger Transport, Promet-Traffic \& Transportation, Vol. 22, No. 5, pp. 389-398, 2010.

[16] Szlosarek, R., Yan, Ch., Kröger, M. and Nußbaumer, Ch.: Energy efficiency of ropeways: a model-based analysis, Public Transport, Vol. 11, No. 3, 2019.

[17] El-Jouzou, H.: A Comparative Study of Aerial Ropeway Transit (ART) Systems. Advantages and Possibilities, M.S. thesis, Faculty 1, Frankfurt University of Applied Sciences, Frankfurt, 2016.

[18] Koller, R. E., Piskoty G. and Zgraggen, M.: Scheme of the Failure Analysis Taking the Example of Profile Wire Breaks in the Support Cable of a Cable Car System, Praktische Metallographie, Vol. 53, No. 12, pp. 798-810, 2016.

[19] Qin, J., Qiao, L., Wan, J., Jiang, M. and Xia Y.: Dynamic analysis of suspension cable based on vector form intrinsic finite element method, in: Proceeding of the Int. Conference on Structural, Mechanical and Materials Engineering (IOP Conf. Series: Materials Science and Engineering, Vol. 248), Seoul, 13-15.07.2017, 012025.

[20] Težak, S. and Toš, Z.: Reliability analysis of operation for cableways by fta (fault tree analysis) method, Promet-Traffic \& Transportation, Vol. 22, No. 3, pp. 163-173, 2010.

[21] Nordin, A. S.: Air rights - A study of urban ropeways from a real estate law perspective, M.S. thesis, Department of Real Estate and Construction Management, Royal Institute of Technology, Stockholm, 2016.

[22] Thaler, H., Wenin, M., Brunner, J., Reiterer, D., Bertotti, M. L., Modanese, G. and Oberhuber, E.: Numerical optimization in cable railway planning, in: Properties and Characterization of Modern
Materials. Advanced Structured Materials, Springer, Vol. 33, pp. 113-124, 2015.

[23] Lagerev, A. V., and Lagerev, I. A.: Design of passenger aerial ropeway for urban environment, Urban Rail Transit, Vol. 5, No. 1, pp. 17-28, 2019.

[24] Lagerev, A. V., Lagerev, I. A. and Tarichko, V. I.: 2019. Impact of design capacity on optimal parameters of freight aerial mono-cable cableways, in: Proceeding of the Int. Conference on Innovations and Prospects of Development of Mining Machinery and Electrical Engineering (IOP Conf. Series: Earth and Environmental Science, Vol. 378), Saint-Petersburg, 24-27.04.2019, 012063 .

[25] Lagerev, A. V. and Lagerev, I. A.: The effect of topography on the choice of optimal step intermediate supports along the line of the cable metro, Nauchno-tekhnicheskiy vestnik Bryanskogo gosudarstvennogo universiteta, Vol. 3, No. 3, pp. 253-272, 2017. (in Russian)

[26] Lagerev, A.,V. and Lagerev, I. A.: Cable transport system "Kanatnoe metro" towers distance optimization, Vestnik Bryanskogo gosudarstvennogo universiteta, No. 4, pp. 22-30, 2014. (in Russian)

[27] Reklaitis, G. V., Ravindran, A. and Ragsdell, K. M.: Engineering optimization. Methods and applications, John Wiley and Sons, New York, 1983.

[28] Shoup, T. E.: A practical guide to computer methods for engineers, Pearson Education Canada, Prentice-Hall, 1979.

\section{СМАҢИВАЊЕ ИНТЕНЗИТЕТА РАДА ПРИ ИЗРАЧУНАВАЮУ ОПТИМАЛНИХ ТЕХНИЧКИХ КАРАКТЕРИСТИКА ЖИЧАРА}

\section{А.В. Лагерев, И.А. Лагерев}

У раду се развија поступак оптимизације техничких карактеристика жичаре - удаљеност и висина међустубова и сила затезања носећих ужади. Проблем оптимизације заснива се на минимизирању трошкова структуре стубова. Смањење интензитета рада при израчунавању полази од чињенице да ће положај минималне тачке објективне функције бити повезан са ограничењима оптимизације. То нам је омогућило да предложимо два начина за смањење интензитета рада при израчунавању: а) смањење димензије проблема оптимизације; б) решење нелинеарне алгебарске једначине је замена за тражење минимума објективне функције. Показано је да предложени алгоритам повећава ефикасност израчунавања. Алгоритам омогућава добијање истих оптималних вредности техничких карактеристика жичаре које даје решење раније развијеног задатка оптимизације, али применом једноставнијих математичких метода. 